\title{
Psychological Well-being Pekerja Informal Sektor Industri Kreatif UMKM di Kota Semarang (Studi Fenomenal pada Kampung Batik Semarangan)
}

\author{
Mochammad Eric Suryakencana Wibowo \\ Universitas Diponegoro \\ Indi Djastuti \\ Universitas Diponegoro \\ ericsuryaa@gmail.com
}

\begin{abstract}
Abstrak
Tujuan dari penelitian ini adalah untuk mengetahui bagaimana kondisi kesejahteraan psikologis dari pekerja informal sektor indusri kreatif UMKM di Kota Semarang, khususnya di Kampung Batik Semarang. Penelitian ini menggunakan 6 dimensi dari kesejahteraan psikologis. Penelitian ini menggunakan metode kualitatif dengan pendekatan fenomenologi dan memuat sejumlah pengrajin batik sebagai partisipan yang berpartisipasi dalam penelitian ini. Pengambilan data menggunakan wawancara mendalam yang dilakukan secara langsung kepada para partisipan tersebut. Hasil dari penelitian menunjukkan bahwa seluruh partisipan memiliki kesejahteraan psikologis yang dipengaruhi oleh masing-masing dimensi. Namun secara khusus, diketahui terdapat dua dimensi yang paling mempengaruhi kesejahteraan psikologis dari para pekerja informal di sana, yakni dimensi hubungan positif dengan orang lain dan dimensi penguasaan lingkungan.
\end{abstract}

Kata Kunci: Kesejahteraan psikologis, pekerja informal, fenomenologi, pengrajin batik, dimensi hubungan positif dengan orang lain, dimensi penguasaan lingkungan.

\section{Pendahuluan}

Nilai perekonomian nasional negara Indonesia saat ini tengah merosot sebagai dampak dari krisis ekonomi yang sedang dialaminya. Krisis yang terjadi melanda kelompok-kelompok usaha menengah atas dengan pendapatan tinggi seperti misalnya pada industri skala besar yang kekuatannya sangat bergantung pada kredit dan impor. Tingkat pengangguran semakin meningkat, banyak karyawan di perusahaan yang terkena PHK sebagai dampak dari krisis ini (Tambunan, 2010). Masalah pengangguran berkontribusi terhadap masalah kesehatan mental dan kesejahteraan psikologis (Winefield, 2010). Tidak jarang para karyawan yang memiliki masalah terkait pekerjaan, mengalami mental health issues atau masalah kesehatan mental. Masalah kesehatan mental dapat mempengaruhi siapa saja di tempat kerja. Stres, depresi, dan kecemasan memiliki konsekuensi besar bagi individu dan masyarakat.

Terdapat banyak studi mengenai masalah-masalah kesehatan mental. Masalah kesehatan mental saat ini juga telah merambah ke ranah manajemen. Para pekerja di sektor perkantoran sering mengalami masalah ini. Hanya seperempat pekerja yang mengatakan bahwa mereka telah melihat perubahan positif dalam upaya-upaya yang dilakukan di tempat kerja mereka selama dua tahun terakhir untuk menunjukkan bahwa kesehatan mental sangatlah penting bagi semua orang (Harvey, 2018). 


\section{Mochammad Eric Suryakencana Wibowo, Indi Djastuti}

Banyak praktik SDM bertujuan untuk meningkatkan kesehatan mental pekerja dengan memanfaatkan konflik dalam lingkungannya. Perspektif ini menganggap ketegangan atau konflik nyata adalah hal normal, dan justru dianggap menguntungkan dan dapat dimanfaatkan oleh pekerja (Loon et al., 2019). Namun, praktik SDM semacam ini justru akan memberi sinyal kepada pekerja bahwa kontribusi mereka tidak dihargai dan tidak dapat membangun hubungan yang saling menguntungkan (Baluch, 2017).

Namun dewasa ini, pekerja yang terdampak oleh masalah kesehatan mental bukan hanya para pekerja kantoran dari sektor formal saja, akan tetapi juga para pekerja sektor informal. Pekerja informal juga sering mengalami keresahan akan pekerjaan dan kondisi kerja yang tidak sesuai dengan harapan. Ini sering kali menjadi penyebab para pekerja informal sangat rentan terhadap masalah kesehatan mental (Sychareun et al., 2016). Digambarkan bahwa pekerjaan pada sektor informal berada pada bagian bawah dari hierarki jenis pekerjaan yang ditandai dengan masalah upah rendah, kondisi, serta lingkungan kerja yang buruk (Williams, 2014).

Pekerja informal bekerja dengan sistem pendapatan rendah dan waktu penerimaan pendapatan yang tidak menentu. Diperkirakan telah terjadi ketimpangan pendapatan yang diterima antara pekerja informal dan pekerja formal di pasar tenaga kerja (Kahyalar et al., 2018). Keberadaan pekerja sektor informal memiliki implikasi penting pada struktur pendapatan. Situasi ini sering disebut sebagai faktor sentral yang melatarbelakangi ketidaksetaraan upah yang mereka terima. Jika dibandingkan dengan pekerja sektor formal, mereka berpenghasilan sangat kurang dari standar yang ditetapkan, karena upah ditetapkan berdasarkan harga pasar atau upah minimum yang berlaku (Njoda Mathurin, 2017).

Pada saat ini, sektor informal diharapkan mampu memberikan kemungkinan bagi para tenaga kerja untuk dapat keluar dari masalah ekonomi dan sosial yang memiliki dampak pada kesehatan mental mereka. Namun, karena sangat sedikitnya pengetahuan serta ketiadaan laporan tentang pertumbuhan di sektor informal, justru ini berdampak pada kesehatan mental seorang pekerja. Pekerja informal memiliki prioritas yang lebih tinggi mengalami gangguan umum kesehatan mental jika dibandingkan dengan mereka-mereka yang bekerja pada sektor formal. Terlebih, sedikitnya ketersediaan laporan tentang pertumbuhan di sektor informal ekonomi yang berdampak pada kesehatan mental seorang pekerja akan menjadi fokus perhatian tersendiri (Ludermir \& Lewis, 2003).

Kesehatan mental tentunya sangat erat kaitannya dengan kesejahteraan psikologis seseorang. Kesehatan mental dan kesejahteraan psikologis saling berkaitan sebagaimana kesehatan mental yang baik akan mengarah pada kesejahteraan psikologis dan kesejahteraan psikologis akan meningkatkan kesehatan mental (Johal \& Pooja, 2016).

Terdapat hubungan dimensi kesejahteraan sebagai penghasil kesejahteraan dalam sistem relasional untuk mengambil perspektif yang berbeda dalam menjawab pertanyaan tentang kesejahteraan dengan menekankan rasionalitas manusia, efektivitas dan pelakunya sehingga menghasilkan kesejahteraan yang afektif untuk diri mereka sendiri (Martela, 2014). Konsep psychological well-being saat ini telah merambah ke ranah manajemen dan telah ada penelitian yang dilakukan oleh kalangan profesi maupun akademisi. Merujuk pada penelitian terdahulu yang telah ditemukan dan digunakan oleh peneliti saat ini sebagai sumber acuan penelitian, konsep psychological well-being telah diteliti di berbagai sektor seperti pada perusahaan, individual, kelompok pekerja dan lain-lain. Hanya saja, masih sedikit penelitian yang meneliti tentang psychological well-being di kalangan pekerja informal terutama pada sektor industri kreatif UMKM. 


\section{Mochammad Eric Suryakencana Wibowo, Indi Djastuti}

Penelitian yang ada tentang kesejahteraan pekerja cenderung berfokus pada kepuasan kerja dan bagaimana cara mereka mengelola kesejahteraan dalam situasi yang memberi mereka kepastian (Martela, 2014). Penelitian di Indonesia sendiri hanya terdapat pada literatur terbatas dalam sebuah ruang lingkup dan generalisasi. Karena tidak adanya laporan penelitian yang diterbitkan mengenai kesejahteraan psikologis, maka tidak ada skala berstandar tervalidasi di Indonesia (Eggleston et al., 2015). Masalah terkait pekerjaan di Indonesia yang cukup populer adalah masalah pengangguran, stres kerja dan kaitannya dengan kesejahteraan psikologis. Sebagian besar penelitian yang dipublikasikan di Indonesia justru menyoroti masalah pengangguran karena adanya konsentrasi terhadap masalah kesehatan mental dan kesejahteraan psikologis yang disebabkan oleh menganggur (Winefield, 2010).

Salah satu alasan mengapa kesejahteraan psikologis menarik untuk diteliti, karena selain dalam bidang pekerjaan hal-hal terkait psikologis tidak mutlak diatur dan sifatnya eksploitatif, terlebih adanya feminisasi pekerjaan oleh gender tertentu yakni wanita sebagai tenaga kerja, kelompok gender ini cenderung diremehkan pada pasar tenaga kerja. Status sosial rendah yang eksploitatif biasanya juga merupakan masalah pada tingkat pekerjaan (Gurtoo, 2017). Dalam penelitian ini, Sentra Kampung Batik Semarang dipilih sebagai objek penelitian karena peneliti menemukan sejumlah fenomena yang terjadi di sana. Diawali dengan seiring berkembangnya kemajuan teknologi dan tuntutan akan pemenuhan sumber daya manusia yang handal, hal ini membuka persaingan bisnis menjadi semakin nyata dan tajam. Industri batik harus mampu bersaing dan masih terdapat terdapat beberapa masalah yang meliputi di dalamnya, termasuk keterbatasan akses modal dan keterampilan pekerja yang rendah (terkait penggunaan teknologi, kemampuan manajerial, akuntansi dan pemasaran), dan hal-hal tersebut justru dapat berguna dalam memberikan pelayanan terbaik kepada konsumen (Kurniati, 2018).

Salah satu masalah yang diungkapkan tersebut, rupanya masih berkaitan dengan masalah-masalah Sumber Daya Manusia (SDM). Temuan masalah-masalah terkait ketenagakerjaan yang dihadapi para pengusaha yang juga berprofesi sebagai pengrajin batik di Kota Semarang tersebut, khususnya pada Sentra Kampung Batik Semarang, mereka justru mengungkapkan bermacam-macam dalih alasan ketika menggambarkan kondisi usahanya. Dalih yang biasa dilontarkan adalah terkait menurunnya transaksi jual beli, kurang gencarnya kegiatan exhibition atau pameran yang diselenggarakan oleh pihak eksternal, produktivitas menurun sehingga omset juga ikut turun dan apabila mereka memiliki pekerja yang dipekerjakan, ini berimbas pada pemberian gaji yang dirasa belum sesuai karena mereka harus menjaga kestabilan antara pemasukan dan pengeluaran agar tidak merugi.

Kemudian jika melihat situasi dan kondisi secara langsung di lingkungan Kampung Batik Semarang, gerai-gerai usaha batik khas Semarangan ini terletak saling berdekatan satu sama lain. Secara teori ekonomi, terdapat persaingan usaha yang terjadi di antara pemilik gerainya. Konsumen dianggap sebagai raja dan menjadi salah satu sumber ekonomi. Oleh karenanya, sumber ekonomi yang terbatas dan hanya berada di satu pihak atau justru dengan adanya lonjakan permintaan atau kebutuhan dari sumber ekonomi di satu pihak, dapat memunculkan konflik antar sesama individu yakni para pemilik gerai atau pengrajin batik dalam memperebutkan sumber-sumber ekonomi tersebut (Fadhilah, 2019).

Temuan masalah lain yang terdapat di Kampung Batik Semarang adalah terkait masalah lingkungan serta hubungan antar warganya. Diketahui bahwa hampir separuh jalan masuk Kampung Batik ini dipenuhi oleh mobil warga diparkir disepanjang gang. Sebelumnya telah ada penawaran akan solusi terkait permasalahan lingkungan ini, namun prosesnya tidak pernah berjalan sesuai harapan dengan arti kata tidak pernah ada kata sepakat antar warga (Zamzami, 2019). Temuan masalah terkait ketiadaan lahan parkir ini mungkin saja hanyalah sebagian kecil 
dari fenomena apa yang sebenarnya terjadi di lingkungan Kampung Batik Semarang. Oleh karena itu, guna mengungkap fenomena-fenomena apa yang sebenarnya terjadi di sana, peneliti akan melanjutkan investigasi lebih lanjut melalui penelitian yang akan peneliti lakukan ini.

Maka, berdasarkan fenomena-fenomena yang ditemukan di Kampung Batik Semarang, peneliti ingin mengidentifikasi serta menganalisis tentang hal dan peristiwa apa yang pernah dialami secara langsung mengenai psychological well-being terkait perasaan dan sikap atau perilaku para pekerja informal sektor industri kreatif UMKM ini yakni pengrajin batik di Kampung Batik Semarang selaku partisipan dalam penelitian ini.

Oleh karena itu, tujuan dari dilakukannya penelitian ini adalah untuk mengetahui tentang bagaimana kondisi psychological well-being pekerja informal sektor indusri kreatif UMKM di Kota Semarang, terkait:

1. Bagaimana penerimaan diri dari pekerja informal sektor industri kreatif UMKM di Kota Semarang?

2. Seperti apa hubungan positif pekerja informal sektor industri kreatif UMKM di Kota Semarang dengan orang lain?

3. Bagaimana pertumbuhan pribadi pekerja informal sektor industri kreatif UMKM di Kota Semarang ini?

4. Apa tujuan hidup dari pekerja informal sektor industri kreatif UMKM di Kota Semarang?

5. Seperti apa penguasaan lingkungan yang dilakukan pekerja informal sektor industri kreatif UMKM di Kota Semarang?

6. Bagaimana kemandirian dari pekerja informal sektor industri kreatif UMKM di Kota Semarang?

\section{Psychological Well-Being dan Dimensi-Dimensinya}

Psychological well-being atau kesejahteraan psikologis adalah fungsi psikologis positif yang muncul dalam diri seseorang dan ini dipengaruhi secara langsung oleh beberapa aspek empiris dan korelasi sosiodemografi. Kesejahteraan ini dieksplorasi melalui studi peristiwa kehidupan dan pengalaman yang dialami oleh manusia sehingga akan diketahui tentang bagaimana sejarah hidupnya dan secara psikologis dapat dikelompokkan ke dalam kategori rentan atau kategori tangguh (Ryff \& Singer, 1996). Kesejahteraan psikologis sering digunakan untuk mendefinisikan kondisi kesehatan mental dan psikis seseorang berdasarkan beberapa pemenuhan kriteria psikologi secara positif (Ryff, 1989).

Psychological well-being merupakan pencapaian secara maksimal atas potensi psikologis yang dimiliki seseorang. Artinya, seseorang tersebut berada pada keadaan untuk dapat menerima sebuah kenyataan dalam kehidupannya saat ini serta menerima kelemahan dan kekuatan yang dimilikinya, membangun hubungan baik dengan banyak orang, memiliki kemampuan untuk berkembang berkelanjutan secara terus menerus dengan mengembangkan potensi yang ada pada dirinya, berkemampuan untuk menentukan tujuan dan arah dalam hidup, adanya kemampuan untuk menguasai serta menciptakan lingkungan yang sesuai dengan keinginannya, dan yang terakhir memiliki kemampuan untuk bertindak secara mandiri sesuai standar diri yang telah ditetapkannya serta tidak bergantung kepada orang lain (Ryff, 1989).

Psychological well-being memiliki keterikatan dalam hubungannya terhadap kepuasan diri, pengharapan, penuh rasa syukur, suasana hati, makna atau arti diri, kebahagiaan, kepuasan dan sikap optimisme, termasuk juga mampu mengenali kekuatan dan mengembangkan minat 
serta bakatnya. Psychological well-being mengarahkan seseorang untuk lebih kreatif dan memahami apa yang saat ini sedang dilakukannya (Bartram \& Boniwell, 2007). Kesejahteraan psikologis juga sangat dipengaruhi oleh konteks kehidupan orang-orang di sekitarnya. Kesejahteraan psikologis cenderung bergantung pada keadaan eksternal individu serta sumber daya dan tantangan yang mereka hadapi (Farrington, 2018).

Model teoritis dari psychological well-being atau kesejahteraan psikologis mencakup sejumlah dimensi kesejahteraan yang berbeda. Menurut Carol D. Ryff, terdapat 6 dimensi psychological well-being atau kesejahteraan psikologis, yaitu:

\section{Penerimaan Diri (Self-Acceptance)}

Penerimaan diri atau self-acceptance merupakan salah satu penggambaran kondisi kesehatan psikis dan mental serta menjadi karakter utama bagi seorang individu dalam mengaktualisasikan diri, dapat berfungsi secara optimal, dan menjadi indikator kematangan diri. Penerimaan diri yang baik dapat ditandai dengan kemampuan seseorang menerima dirinya apa adanya. Kemampuan tersebut dapat menjadikan seseorang untuk bersikap positif pada dirinya sendiri dan kehidupan yang sedang dijalaninya. Hal ini menandakan bahwa kesejahteraan psikologis seseorang sangat tinggi (Ryff, 1989).

Seseorang yang dapat menerima dirinya secara baik ditandai dengan dapat mengakui dan menerima berbagai aspek yang ada dalam diri serta kehidupannya, baik secara positif maupun negatif, dapat menerima kejadian masa lalunya dan memiliki harapan di masa mendatang (Ryff \& Singer, 2006).

Penerimaan diri yang baik ditandai dengan kemampuan menerima selama tiga masa, yakni masa lalu, masa saat ini, dan masa mendatang. Pengeksplorasian perkembangan masa lalu, masa saat ini, dan masa depan dimulai dengan menggambarkan sejarahnya, kemudian melalui perkembangan dekade terakhir hingga ke tempat seseorang berada pada masa sekarang, dan penentuan masa mendatangnya (Simonen, 2014).

\section{Hubungan Positif Dengan Orang Lain (Positive Relations with Others)}

Hubungan positif dengan orang lain atau positive relations with others merupakan kemampuan seseorang untuk membangun dan memelihara hubungan yang dapat bermanfaat satu sama lain. Selain itu, dimensi ini juga mengatur hubungan untuk saling saling mempercayai, hangat dan memuaskan dengan orang lain. Mereka tentu memiliki rasa afeksi dan empati yang sangat kuat. Penekanan lainnya pada dimensi ini ditandai dengan adanya kemampuan untuk mencintai orang lain sebagai salah satu komponen kesehatan psikis dan mental. Seorang individu yang memiliki hubungan positif dengan orang lain, tentu akan memiliki rasa afeksi dan empati yang sangat kuat (Ryff \& Singer, 2006).

Hubungan secara positif dapat dicirikan berdasarkan sifat-sifatnya yang menggambarkan masing-masing pihak saling ketergantungan, cara-cara yang dilakukan oleh individu untuk mengubah perilaku mereka guna berkoordinasi dengan tindakan dan preferensi orang lain. Jadi, orang-orang yang terlibat dalam sebuah hubungan, apakah akan menanggapi atau tidak, menunjukkan keprihatinan, kemampuan, dan ekspresi emosional mereka, menyesuaikan perilaku mereka untuk kepentingan bersama atau tidak, mereka menipu diri mereka sendiri atau tidak, mereka bereaksi terhadap perilaku satu sama lain dan mampu menerima keadaan, kemalangan, dan kebahagiaan serta mereka menyadari bahwa saling ketergantungan dalam mengatur setiap kehidupan sehari-hari dan untuk rencana jangka panjangnya (Reis \& Collins, 2004). 


\section{Pertumbuhan Pribadi (Personal Growth)}

Pertumbuhan pribadi atau personal growth merupakan kemampuan seseorang untuk mengembangkan serta memperkaya diri sendiri dengan cara mengasah ilmu pengetahuan, keterampilan dan potensi yang ada dalam dirinya. Seseorang yang memiliki kemampuan ini akan menunjukkan ciri-ciri khusus yakni menjadi individu yang kreatif, memiliki keterbukaan diri, selalu tertarik pada hal-hal baru, ingin terus belajar dan memiliki kebutuhan untuk mengaktualisasikan dirinya (Ryff \& Singer, 2006). Pertumbuhan pribadi melibatkan kepribadian secara langsung dan pengembangan keterampilan tertentu. Secara umum ini digambarkan sebagai pertumbuhan yang melibatkan pengembangan yang sengaja dilakukan oleh seseorang di sepanjang hidupnya (Bauer \& McAdams, 2004).

Pertumbuhan pribadi mengacu pada proses seumur hidup untuk meningkatkan kesadaran diri seseorang, identitas, mengembangkan bakat, dan membangun sumberdaya manusia yang pada akhirnya akan meningkatkan kualitas hidup seseorang atau mungkin kinerja seseorang di tempat kerja. Pertumbuhan pribadi dianggap sebagai perubahan dalam diri seseorang secara afektif, kognitif, maupun perilaku, dan umumnya dianggap sebagai hal positif yang membuat individu menjadi semakin "lebih lengkap dan berfungsi secara penuh" (Le Cunff, 2019).

\section{Tujuan Hidup (Purpose In Life)}

Tujuan hidup atau purpose in life merupakan sebuah dimensi kesejahteraan yang membantu seseorang menemukan makna dan tujuan dalam hidupnya, termasuk memiliki pemahaman yang jelas tentang tujuan ia hidup di dunia, memiliki keterarahan dan intensionalitas. Seseorang dengan kemampuan ini memiliki tujuan dalam hidup dan rasa terarah, merasakan adanya keberartian pada kehidupan sekarang dan masa lalu, memiliki keyakinan yang memberi harapan hidup, serta adanya keinginan yang ingin dicapai (Ryff \& Singer, 2006).

Tujuan hidup memberikan perasaan kepada seseorang akan adanya tujuan dan makna hidup. Definisi lainnya menekankan pemahaman yang jelas untuk tujuan hidup sebagai perasaan terarah dan intensionalitas. Perkembangan teori rentang waktu telah merujuk tujuan hidup pada perubahan maksud atau tujuan dalam hidup, seperti menjadi produktif dan kreatif atau mencapai integrasi emosional dalam kehidupan selanjutnya (akhirat). Jadi, tujuan hidup berfungsi secara positif agar seseorang memiliki tujuan, niat, dan rasa keterarahan, yang semuanya berkontribusi pada perasaan bahwa hidup itu bermakna (Ryff, 1989).

\section{Penguasaan Lingkungan (Environment Mastery)}

Penguasaan lingkungan atau environmental mastery merupakan salah satu dimensi kesejahteraan yang menjelaskan tentang kapasitas seseorang untuk mengelola kehidupannya dengan dunia sekitarnya (lingkungan) yang dilakukan secara efektif (Ryff \& Keyes, 1995). Seseorang dengan penguasaan lingkungan yang baik memiliki kemampuan untuk menciptakan lingkungan yang sesuai dengan kondisi fisik dirinya (Perron, 2006). Dengan kata lain, ia memiliki kemampuan dalam menghadapi kejadian-kejadian di luar kendali dari dirinya. Jadi, penguasaan lingkungan mengacu pada kemampuan seseorang untuk mengendalikan dan 
mengelola lingkungan, serta kemanjuran seseorang dalam memilih lingkungan yang sesuai dengan tujuan dan kebutuhan (Hill \& Allemand, 2010).

Hal ini juga berlaku ketika seseorang tersebut mampu memanipulasi keadaan sehingga menyesuaikan dengan kebutuhan dan prinsip nilai-nilai pribadi yang dipegangnya, mampu dalam pengembangan diri secara kreatif dan inovatif, memiliki penguasaan dan kompetensi dalam mengelola lingkungan, mengendalikan berbagai kegiatan eksternal yang rumit dan kompleks, dapat memanfaatkan peluang di sekitarnya secara efektif, dapat memilih atau menjadikan situasi dan kondisi yang sesuai dengan pribadinya. Sementara itu, seseorang dengan ketidakmampuannya dalam penguasaan lingkungan ditandai dengan adanya selalu kesulitan mengelola urusan sehari-hari, merasa tidak mampu mengubah situasi dan kondisi di sekitarnya, tidak menyadari peluang di sekitarnya, dan kurang memiliki kendali atas dunia (lingkungan) luar (Ryff, 1989).

Penguasaan lingkungan menekankan penciptaan dan pemilihan lingkungan yang baik dan tepat (Garcia et al., 2014). Penguasaan lingkungan adalah bentuk kontrol. Kontrol sendiri telah didefinisikan sebagai harapan individu tentang kemampuannya sendiri untuk mencapai hasil yang diharapkan. Individu yang tinggi dalam penguasaan lingkungannya akan merasakan kompetensi dalam mengelola tuntutan lingkungan dan dapat mengubah atau meningkatkan konteks kehidupan sesuai dengan kebutuhan mereka. Ini juga dapat menjelaskan mengapa seseorang berusia lebih tua akan memiliki kontrol yang lebih tinggi terhadap lingkungan. Mereka yang memiliki kontrol dan kendali atas lingkungan akan jarang menunjukkan masalah antara lingkungan dengan stres harian yang berat yang mungkin dirasakannya sehari-hari (Montpetit \& Tiberio, 2016).

\section{Kemandirian (Autonomy)}

Kemandirian atau autonomy adalah sikap dan perilaku yang dilakukan oleh seseorang atas dorongan dirinya sendiri tanpa adanya pengaturan serta arahan dari orang lain. Kemandirian atau otonomi berarti mengatur diri sendiri (Collier, 2014). Seseorang dengan kemandirian yang baik, cenderung memiliki kemampuan untuk menentukan nasibnya sendiri dan mandiri, mampu menolak tekanan sosial, mampu berpikir dan bertindak dengan cara-cara tertentu, mampu mengatur perilaku dari dalam dirinya sendiri, dan dapat mengevaluasi diri menggunakan standar-standar pribadi yang telah ditetapkannya (Ryff \& Singer, 2006). Kemandirian sangat berfungsi penuh ketika seseorang tidak perlu mencari persetujuan dari orang lain untuk bersikap dan bertindak, akan tetapi ia dapat mengevaluasi dirinya sendiri melalui standar-standar pribadinya. Kemandirian juga berguna untuk memberi seseorang tentang rasa kebebasan dari norma-norma yang mengatur kehidupan sehari-harinya (Ryff, 1989).

Otonomi atau kemandirian melibatkan pengertian bahwa seseorang akan menjadi diri sendiri atau mampu bertindak sesuai dengan keyakinan atau keinginannya tanpa adanya gangguan dari orang lain. Dalam penerapannya, ciri-ciri pribadi yang mandiri didasarkan pada tindakan atau pikiran yang menggambarkan adanya kebebasan, rasionalitas, dan konsistensi dengan preferensi pribadi. Istilah otonomi sendiri meliputi beragam makna yang dianggap berkualitas, seperti aturan diri, penentuan nasib sendiri, kebebasan menentukan tujuan, individualitas, independensi, dan pengetahuan dalam diri. Dalam pemikiran secara etis, hal-hal tersebut diidentifikasi dengan kualifikasi dari penegasan diri, sikap refleksi kritis (introspeksi diri dan pengevaluasian diri), tanggung jawab, ketiadaan sebab-sebab eksternal, dan 


\section{Mochammad Eric Suryakencana Wibowo, Indi Djastuti}

pengetahuan atas minat seseorang. Seluruhnya terhubung dengan tindakan, kepercayaan, prinsip, alasan untuk bertindak dan menetapkan aturan (Agich, 2009).

\section{Metode Penelitian}

Jenis penelitian yang digunakan adalah penelitian dengan metode kualitatif. Metode kualitatif sebagai metode penguji dan penjawab pertanyaan tentang apa, di mana, kapan, bagaimana, dan mengapa seseorang bersikap dan berperilaku dengan cara-cara tertentu terhadap permasalahan yang lebih spesifik (Oun \& Bach, 2014). Metode kualitatif dapat diartikan sebagai sebuah metode penelitian yang berguna mendeskrispsikan fenomenafenomena berdasarkan dari sudut pandang partisipan, mengungkap bermacam-macam realita dan mengembangkan suatu pemahaman holistik tentang fenomena pada konteks tertentu (Hilal et al., 2013). Penelitian kualitatif adalah sistem dan pendekatan subjektif yang bertujuan menjelaskan serta menyoroti pengalaman dalam kehidupan individu sehari-hari (Khan, 2014).

Penelitian kualitatif ini menggunakan pendekatan fenomenologi. Peneliti ingin mengidentifikasi dan menganalisis bagaimana dan seperti apa kesejahteraan psikologis atau psychological well-being dari para pekerja informal sektor industri kreatif UMKM pada Kampung Batik Semarangan di Kota Semarang. Oleh karena itu, berdasarkan dari pengalaman dan peristiwa yang pernah dialami serta dirasakan secara langsung oleh para pekerja informal tersebut, pendekatan fenomenologi adalah pendekatan yang paling cocok digunakan dalam penelitian ini. Pendekatan fenomenologi merupakan pendekatan untuk mempelajari maupun memahami sebuah pengalaman hidup seorang manusia (Tuffour, 2017).

Teknik yang berguna dalam pengumpulan data diperoleh melalui observasi lapangan dan kegiatan wawancara, yang biasa disebut dengan wawancara mendalam atau in-depth interview. Wawancara mendalam bertujuan memperoleh hal-hal secara mendetail mengenai fenomena atau kasus yang sedang diteliti. Tujuan lainnya adalah untuk mendapat "hal" yang belum nampak. Perolehan data in-depth interview dapat dilakukan analisis menggunakan Interpretative Phenomenological Analysis (IPA).

Pengambilan data dalam penelitian kualitatif ini dilakukan selama kurang lebih 2 minggu atau dimulai sejak tanggal 16 September 2019 dan berakhir pada tanggal 30 September 2019. Seluruh proses kegiatan wawancara didokumentasikan ke dalam bentuk audio dan visual berupa rekaman suara dan rekaman video. Pengambilan data melibatkan sejumlah partisipan yang bersedia untuk terlibat di dalam penyusunan penelitian ini. Sejumlah 6 orang partisipan telah berhasil diwawancarai dan pemilihan kriteria partisipan penelitian telah dipilih secara tepat.

\section{Sampel dan Populasi}

Dalam menentukan sampel dan populasi, peneliti berusaha mendapatkan individuindividu dari kelompok pekerja informal yang ada di sentra usaha UMKM yang terkait pada penelitian ini. Penyebutan individu yang terlibat dalam kegiatan wawancara pada penelitian ini menggunakan sebutan "partisipan". Berdasarkan jenis penelitian kualitatif yang digunakan, maka akan digunakan partisipan dari Sentra Kampung Batik Semarangan yang berlokasi di Jl. Batik Tengah (Gang Batik), Kelurahan Rejomulyo, Bubakan, Kecamatan Semarang Timur, Kota Semarang, Jawa Tengah 50227. Terdapat populasi pengrajin batik khas Semarang yang 
terletak pada lokasi penelitian tersebut, sehingga peneliti nantinya akan memilih partisipan secara tepat dari salah satu tempat atau masing-masing tempat yang bertujuan agar memudahkan proses pengambilan data penelitian.

Mengacu pada penentuan partisipan oleh Ryff (2006), partisipan yang dipilih akan didasarkan pada 3 kelompok usia, yaitu usia muda (young), menengah (middle), dan usia lanjut (old). Peneliti telah berhasil mendapatkan serta mewawancarai partisipan-partisipan secara tepat. Nama-nama partisipan beserta nama gerai butik milik partisipan dalam penelitian ini telah peneliti samarkan dan dituliskan dengan menggunakan nama pseudonym. Penggunaan nama samaran adalah prinsip penelitian yang baik. Atasnya, peneliti bertanggung jawab untuk menjaga anonimitas dan kerahasiaan.

Berikut ini adalah profil partisipan yang telah dan bersedia diwawancarai dalam penelitian ini:

1. Bapak Bubu selaku partisipan ke-1.

Pemilik gerai butik batik Djenggo, berusia 64 tahun, beragama Islam, dan tidak menikah.

2. Ibu Fafa selaku partisipan ke-2.

Pemilik gerai butik batik Vaganza, berusia 58 tahun, beragama Islam, dan sudah pernah menikah namun bercerai.

3. Ibu Vivi selaku partisipan ke-3.

Pemilik gerai butik batik Rawon, berusia 30 tahun, beragama Islam, dan sudah menikah.

4. Bapak Gigi selaku partisipan ke-4.

Pemilik gerai butik batik Sulfida, berusia 46 tahun, beragama Islam, dan sudah menikah.

5. Ibu Nini selaku partisipan ke-5.

Pemilik gerai butik batik Hayati, berusia 42 tahun, beragama Islam, dan sudah menikah untuk yang kedua kalinya.

6. Bapak Zazal selaku partisipan ke-6.

Pemilik gerai butik batik Belibis, berusia 23 tahun, beragama Islam, dan belum menikah.

\section{Data Deskriptif}

Peneliti telah berhasil melakukan collecting data kepada partisipan yakni para pekerja/pengrajin batik di Kampung Batik Semarang. Adapun partisipan yang telah bersedia diwawancarai yaitu sebanyak 6 orang. Partisipan terpilih yang diwawancarai telah dianggap tepat dan masuk ke dalam kriteria yang diharapkan oleh peneliti. Seluruh proses kegiatan wawancara didokumentasikan ke dalam bentuk audio dan visual berupa rekaman suara dan rekaman video. Hal ini dilakukan guna mempermudah peneliti dalam memindahkan konten dari rekaman tersebut menjadi bentuk transkrip wawancara yang nantinya bentuk transkrip wawancara tersebut siap untuk diolah.

Penelitian diawali ketika peneliti datang mengunjungi lokasi penelitian, yakni Kampung Batik Semarang. Selama melakukan proses kegiatan wawancara, peneliti disambut baik dan hangat dari masyarakat yang berada di Kampung Batik Semarang. Para partisipan pun menyambut baik tujuan dari peneliti untuk melakukan kegiatan penelitian di lingkungan mereka. Peneliti terlebih dahulu datang ke Kampung Batik Semarang pada tanggal 16 


\section{Mochammad Eric Suryakencana Wibowo, Indi Djastuti}

September 2019 dan bertemu dengan seseorang yang berwenang memberikan izin untuk melakukan penelitian. Peneliti bertemu dengan Ibu Tri selaku ketua RW setempat. Ketika peneliti bertemu dengan beliau, peneliti mengutarakan maksud dan tujuan berkunjung ke Kampung Batik Semarang dan hal ini disambut baik oleh yang bersangkutan.

Ibu Tri menuturkan bahwa di Kampung Batik Semarang sering digunakan sebagai objek penelitian dari berbagai institusi akademik maupun perusahaan, sehingga ketika pertama kali beliau bersedia menemui peneliti di rumahnya, Ibu Tri secara otomatis langsung mengetahui maksud dan tujuan peneliti datang ke sana. Segala kemudahan dan kelancaran dalam proses collecting data di lapangan ini bukan berarti tanpa hambatan. Peneliti juga sempat menghadapi kendala dan hambatan. Sejumlah orang yang awalnya menjadi target peneliti untuk dijadikan partisipan dalam penelitian, mereka tidak bersedia untuk diwawancarai dengan berbagai macam alasan yang disampaikannya. Alhasil, peneliti harus mencari lagi partisipan mana saja yang bersedia untuk diwawancarai dan tepat sesuai kriteria yang diharapkan.

Peneliti sangat meyakini bahwa apa yang dituturkan dan diceritakan oleh seluruh partisipan adalah benar-benar peristiwa dan kejadian yang mereka hadapi, alami dan rasakan sendiri. Keyakinan ini tentunya berguna dalam membangun sebuah kredibilitas baik pada data yang disajikan beserta hasil dan pembahasannya. Peneliti mendapati bahwa faktor demografis juga sangat berpengaruh dalam mencerminkan serta menggarisbawahi lika-liku perjalanan kehidupan dari masing-masing partisipan. Masing-masing dari mereka memiliki kisahnya masing-masing yang terungkap dalam proses kegiatan wawancara.

Dari hasil dokumentasi audio visual yang telah peneliti dapatkan, kemudian hasil tersebut diolah menjadi bentuk transkrip wawancara berupa kata-kata. Berdasarkan bentuk transkrip wawancara dengan seluruh partisipan, selanjutnya peneliti memindahkan transkrip wawancara tersebut ke dalam bentuk matriks hasil wawancara. Pada matriks hasil wawancara tersebut kemudian muncul berbagai macam codes, categories dan sub categories berdasarkan masing-masing dimensi yang terdapat pada teori psychological well-being yang digunakan. Kemunculan berbagai macam codes, categories dan sub categories ini akan memudahkan peneliti dalam menyusun pembahasan dan interpretasi.

\section{Pembahasan}

Kesejahteraan psikologis atau psychological well-being memiliki 6 dimensi sebagai pilar-pilar utama di dalamnya. Masing-masing dimensi telah mengatur kesejahteraan psikologis secara eudaimonic, yang artinya lebih menekankan pada fungsi fisiologis secara efektif tentang bagaimana setiap individu harus bersikap dan berperilaku (Kasser et al., 2014). Berdasarkan hasil wawancara dan analisis data penelitian mengenai psychological well-being pekerja informal sektor industri kreatif UMKM di Kota Semarang studi fenomenologi pada sentra Kampung Batik Semarangan, maka dapat disimpulkan sebagai berikut:

\section{Penerimaan Diri (Self-Acceptance)}

Penerimaan diri memberikan dasar yang kuat kepada para partisipan untuk dapat menerima keadaan dirinya secara baik dalam menjalani kehidupannya saat ini sehingga mampu memandang sebuah harapan di masa mendatang, meskipun berbagai macam peristiwa memilukan yang terjadi di masa lalu masih membekas dan meninggalkan kesedihan jika masih terpikirkan, hingga memiliki keterikatan terhadap kehidupan saat ini. Maka, kesejahteraan 
psikologis dari pekerja informal sektor industri kreatif UMKM di Kota Semarang, khususnya di Kampung Batik Semarang terkait dimensi penerimaan diri atau self-acceptance adalah mereka mampu menerima keadaan dirinya masing-masing secara baik. Meski diketahui bahwa masing-masing partisipan memiliki berbagai macam peristiwa yang terjadi di masa lalunya, pada kenyataannya mereka mampu menerima keadaan diri dan kehidupannya pada masa saat ini secara baik.

\section{Hubungan Positif dengan Orang Lain (Positive Relations with Others)}

Hubungan positif dengan orang lain menjadi sebuah cerminan tentang bagaimana hubungan dan interaksi yang dibangun serta dijalin oleh para partisipan dengan orang lain. Meskipun di dalam kehidupan keluarga dan kehidupan pribadinya, mereka dapat membangun sebuah hubungan yang baik, faktanya mayoritas partisipan diketahui pernah dan bahkan sedang berkonflik dengan orang lain di dalam kehidupan sosialnya. Maka, kesejahteraan psikologis dari pekerja informal sektor industri kreatif UMKM di Kota Semarang, khususnya di Kampung Batik Semarang terkait dimensi hubungan positif dengan orang lain atau positive relations with others adalah telah terjadi ketidakharmonisan dan terjalin hubungan yang buruk. Hal ini lantaran dipicu oleh berbagai masalah dan konflik yang terjadi di dalam hubungan sosial mereka.

\section{Pertumbuhan Pribadi (Personal Growth)}

Pertumbuhan pribadi telah menunjukkan bahwa sebagian besar partisipan memiliki minat dan ketertarikan akan sebuah perubahan pada dirinya agar menjadi individu yang lebih baik lagi dengan cara mengembangkan diri dan mengasah potensi yang dimiliki, meskipun terdapat salah seorang partisipan yang tidak tertarik untuk mengembangkan diri dan mengasah potensi yang dimilikinya guna menjadi individu yang lebih baik lagi. Maka, kesejahteraan psikologis dari pekerja informal sektor industri kreatif UMKM di Kota Semarang, khususnya di Kampung Batik Semarang terkait dimensi pertumbuhan pribadi atau personal growth adalah dinilai baik karena mereka selalu menumbuhkembangkan pribadinya dengan cara-cara tertentu yang bermanfaat. Menyadari potensi yang dimiliki, memiliki keinginan untuk selalu berubah, dan membuka diri terhadap hal-hal baru adalah upaya-upaya yang mereka lakukan agar diri mereka menjadi semakin lebih baik lagi.

\section{Tujuan Hidup (Purpose in Life)}

Tujuan hidup memiliki peran yang besar guna mengarahkan seluruh partisipan menuju pada proses pencapaian keinginan dan harapan yang telah ditetapkan. Tujuan hidup juga membantu para partisipan untuk menemukan makna dalam kehidupan serta membantu mereka untuk menyadari ke mana tujuan akhir manusia hidup di dunia. Maka, kesejahteraan psikologis dari pekerja informal sektor industri kreatif UMKM di Kota Semarang, khususnya di Kampung Batik Semarang terkait dimensi tujuan hidup atau purpose in life adalah memiliki tujuan hidup religius. Meski memiliki keinginan dan harapan yang bersifat duniawi yang ingin diwujudkan, namun pada kenyataannya religiusitas dalam diri telah membantu seluruh partisipan untuk dapat meningkatkan kepuasan batin dan kebahagiaan hidup mereka melalui upaya-upaya akan pemenuhan kebutuhan rohaninya. Selain itu, karena seluruh partisipan merupakan seorang Muslim, Islam sendiri telah menjawab tentang apa yang menjadi tujuan hidup mereka sebagai manusia selama hidup di dunia, yaitu untuk beribadah kepada Allah SWT dan semua itu dilakukan secara Lillahi Ta'ala atau berarti "karena Allah Ta'ala". 


\section{Mochammad Eric Suryakencana Wibowo, Indi Djastuti}

\section{Penguasaan Lingkungan (Environmental Mastery)}

Penguasaan lingkungan mendukung kemampuan para partisipan dalam mengelola, mengendalikan dan menyesuaikan diri mereka masing-masing terhadap lingkungannya. Meski para partisipan mampu melihat peluang serta dapat mengambil keuntungan yang tercipta dari lingkungan saat ini, namun pada kenyataannya, sejumlah partisipan justru menunjukkan bahwa mereka tidak memiliki pengelolaan dan pengendalian yang baik terhadap lingkungannya. Dalam arti lain, lingkungan tidak dapat diubah atau dimanipulasi menjadi seperti apa yang mereka harapkan. Berbagai penyebab telah menjawab mengapa lingkungan yang tidak dapat dikelola dan tidak dapat dikendalikan tersebut dapat terjadi. Maka, kesejahteraan psikologis dari pekerja informal sektor industri kreatif UMKM di Kota Semarang, khususnya di Kampung Batik Semarang terkait dimensi penguasaan lingkungan atau environmental mastery adalah tidak dapat menguasai lingkungan karena tidak memiliki kontrol atas berbagai permasalahan yang terjadi pada lingkungannya saat ini.

\section{Kemandirian (Autonomy)}

Kemandirian menjadi gambaran bagaimana pribadi dari masing-masing partisipan berkemampuan untuk dapat mengatur segala aktivitas dan kegiatan yang dilakukan secara sendiri tanpa adanya bantuan dari orang lain. Para partisipan memiliki independensi, mampu menentukan arah dirinya di masa mendatang, memiliki aturan-aturan diri yang telah diterapkan dan tidak menunjukkan ketidakmampuan diri dalam hal kemandirian. Maka, kesejahteraan psikologis dari pekerja informal sektor industri kreatif UMKM di Kota Semarang, khususnya di Kampung Batik Semarang terkait dimensi kemandirian atau autonomy adalah para partisipan merupakan individu yang mandiri dan kemampuan ini bermanfaat bagi mereka untuk dapat mengatur segala hal yang dilakukan secara sendiri tanpa adanya bantuan dari orang lain.

\section{Kesimpulan}

Dapat diketahui bahwa masing-masing dimensi memiliki hasil yang berdampak pada kesejahteraan psikologis dari masing-masing partisipan. Terkait dimensi penerimaan diri atau self-acceptance, seluruh partisipan diketahui telah mampu menerima keadaan dirinya masingmasing secara baik. Meski dari masing-masing partisipan memiliki berbagai macam peristiwa yang terjadi di masa lalunya, pada kenyataannya mereka mampu menerima keadaan diri dan kehidupannya pada masa saat ini secara baik. Terkait dimensi hubungan positif dengan orang lain atau positive relations with others, diketahui bahwa telah terjadi ketidakharmonisan dan terjalin hubungan yang buruk di antara sejumlah partisipan. Hal ini lantaran dipicu oleh berbagai masalah dan konflik yang terjadi di dalam hubungan sosial mereka.

Terkait dimensi pertumbuhan pribadi atau personal growth, mayoritas partisipan dinilai selalu menumbuhkembangkan pribadinya dengan cara-cara tertentu yang bermanfaat. Mereka senantiasa menyadari potensi yang dimiliki, memiliki keinginan untuk selalu berubah, dan membuka diri terhadap hal-hal baru adalah upaya-upaya yang mereka lakukan agar diri mereka menjadi semakin lebih baik lagi. Terkait dimensi tujuan hidup atau purpose in life, seluruh partisipan diketahui memiliki tujuan hidup religius. Meski memiliki keinginan dan harapan yang bersifat duniawi yang ingin diwujudkan, namun pada kenyataannya religiusitas dalam diri telah membantu seluruh partisipan untuk dapat meningkatkan kepuasan batin dan kebahagiaan hidup mereka melalui upaya-upaya akan pemenuhan kebutuhan rohaninya. 


\section{Mochammad Eric Suryakencana Wibowo, Indi Djastuti}

Terkait dimensi penguasaan lingkungan atau environmental mastery, sebagian besar dari partisipan tidak dapat menguasai lingkungan karena tidak memiliki kontrol atas berbagai permasalahan yang terjadi pada lingkungannya saat ini. Dan yang terakhir, terkait dimensi kemandirian atau autonomy, sebagian besar dari partisipan merupakan individu yang mandiri dan kemampuan ini bermanfaat bagi mereka untuk dapat mengatur segala hal yang dilakukan secara sendiri tanpa adanya bantuan dari orang lain. Berdasarkan hasil tersebut pula, diketahui bahwa dimensi hubungan positif dengan sesama (positive relations with others) dan dimensi penguasaan lingkungan (environmental mastery) adalah yang paling mempengaruhi kesejahteraan psikologis dari pekerja informal sektor industri kreatif UMKM di Kota Semarang, khususnya di Kampung Batik Semarang.

Penelitian ini juga berkontribusi atas sejumlah temuan-temuan baru yang sebelumnya belum pernah terungkap. Beberapa di antaranya adalah terdapat permasalahan terkait hubungan antar sesama pengrajin batik di Kampung Batik Semarang, terkait komitmen rendah dari para pengrajin batik di sana dalam menghargai hak cipta atau hak paten dari masing-masing pengrajin batik dan rendahnya minat serta ketertarikan masyarakat lainnya yang tinggal di sana untuk ikut berpartisipasi mengembangkan dan melestarikan kebudayaan membatik di lingkungan Kampung Batik Semarang.

\section{Implikasi dan Agenda Penelitian}

Dari hasil penelitian ini, diketahui masih terdapat beberapa pengrajin batik yang pernah terlibat konflik dan bahkan ada yang masih berkonflik hingga saat ini. Hal ini semakin diperkuat dengan adanya kondisi persaingan usaha di lingkungan tersebut yang dinilai oleh beberapa partisipan tidak sehat, serta ketidakaktifan dan minat rendah dari masyarakat lainnya yang tinggal di lingkungan Kampung Batik Semarang untuk ikut berpartisipasi dalam upayaupaya melestarikan dan mengembangkan batik, perlu menjadi perhatian khusus. Diharapkan dari hasil tersebut dapat memberikan implikasi akan kesejahteraan psikologis, tidak hanya bagi para pengrajin batik namun juga bagi masyarakat lainnya. Peneliti menyarankan agar mereka dapat memperbaiki serta dapat meningkatkan kesejahteraan psikologisnya, sehingga hal tersebut akan memiliki manfaat dan dampak yang lebih baik lagi. Terlebih, Belum banyak penelitian di Indonesia yang meneliti tentang bagaimana kesejahteraan psikologis atau psychological well-being terutama dari kalangan pekerja maupun pelaku organisasi. Terlebih, penelitian tentang kesejahteraan psikologis di Indonesia sendiri hanya terdapat pada literatur terbatas dalam sebuah ruang lingkup dan generalisasi sehingga tidak ada skala berstandar yang dapat dijadikan acuan (Eggleston et al., 2015).

Agenda untuk penelitian mendatang, agar peneliti selanjutnya dapat melakukan penelitian lebih lanjut tentang bagaimana kesejahteraan psikologis atau psychological wellbeing dari berbagai kalangan dan latar belakang pekerja. Penelitian mendatang tidak harus selalu berfokus meneliti tentang bagaimana kesejahteraan psikologis atau psychological wellbeing dari kalangan pekerja sektor informal saja, akan tetapi juga dapat menyasar pada kalangan pekerja dari sektor formal, sehingga diharapkan dapat memunculkan temuan atau fenomena baru yang sebelumnya belum pernah terungkap. Kemudian penelitian mendatang juga dapat meneliti tentang korelasi antara kesejahteraan psikologis seseorang dengan kesejahteraan ekonominya. Dapat dilakukan penelitian tentang apakah keduanya saling memiliki keterkaitan, atau justru tidak. 
INOBIS: Jurnal Inovasi Bisnis dan Manajemen Indonesia

Vol.03, No.01, Desember 2019

Mochammad Eric Suryakencana Wibowo, Indi Djastuti

\section{Daftar Pustaka}

Agich, G. J. (2009) "Key Concepts: Autonomy". Philosophy, Psychiatry \& Psychology, (November), 267-269.

Baluch, A. M. (2017) "Employee perceptions of HRM and well-being in nonprofit organizations: unpacking the unintended". International Journal of Human Resource Management, 28(14), 1912-1937.

Bartram, D., \& Boniwell, I. (2007) "The science of happiness: Achieving sustained psychological wellbeing". In Practice, 29(8), 478-482.

Bauer, J. J., \& McAdams, D. P. (2004) "Personal growth in adults' stories of life transitions". Journal of Personality, 72(3), 573-602.

Collier, J. (2014) What is Autonomy? Diakses dari https://www.researchgate.net/publication/28763485_What_is_Autonomy pada tanggal 28 Desember 2019.

Eggleston, E. (2015) "Measuring Women's Psychological Well-Being in Indonesia". Women \& Health, 32(4), 17-32.

Fadhilah, M. (2019) "Penegakan Hukum Persaingan Usaha Tidak Sehat Oleh Komisi Pengawas Persaingan Usaha ( KPPU ) Dalam Kerangka Ekstrateritorial". Jurnal Wawasan Yuridika, 3(1), 55-72.

Farrington, S. M. (2018) "Psychological Well-Being and Perceived Financial Performance: an SME Perspective". South African Journal of Business Management, 48(4), 47-56.

Garcia, D., Nima, A. Al, \& Kjell, O. N. E. (2014) "The Affective Profiles, Psychological WellBeing, and Harmony: Environmental Mastery and Self-Acceptance Predict the Sense of a Harmonious Life. PeerJ, 2014(1), 1-21.

Gurtoo, A. (2017) "Women in the Informal Economy: Psychological Well-Being and the Empowerment Trap". Sociological Bulletin, 66(3), 316-331.

Harvey, B. (2018) What Companies Can Do to Help Employees Address Mental Health Issues. Diakses dari https://hbr.org/2018/12/what-companies-can-do-to-help-employeesaddress-mental-health-issues pada tanggal 10 November 2019.

Hilal AlYahmady, H., \& Said Al Abri, S. (2013) "Using Nvivo for Data Analysis in Qualitative Research". International Interdisciplinary Journal of Education (Vol. 2).

Hill, P. L., \& Allemand, M. (2010) "Forgivingness and Adult Patterns of Individual Differences in Environmental Mastery and Personal Growth". Journal of Research in Personality, $44(2), 245-250$.

Johal, S. K., \& Pooja, M. (2016) "Relationship Between Mental Health and Psychological Well Being of Prospective Female Teachers". IOSR Journal of Research \& Method in Education, 6(1), 1-6.

Kahyalar, N., Fethi, S., Katircioglu, S., \& Ouattara, B. (2018) "Formal and Informal Sectors: Is There Any Wage Differential?". Service Industries Journal, 38(11-12), 789-823.

Kasser, T. (2014) "Changes in Materialism, Changes in Psychological Well-Being: Evidence 
from Three Longitudinal Studies and an Intervention Experiment". Motivation and Emotion, 38(1), 1-22.

Khan, S. N. (2014) "Qualitative Research Method - Phenomenology". Asian Social Science, 10(21), 298-310.

Kurniati, E. D. (2018) "Batik SMEs Efficiency and Entrepreneurship Role in Innovation". JEJAK: Jurnal Ekonomi Dan Kebijakan, 11(2), 375-389.

Le Cunff, A.-L. (2019) "Mindframing: A Proposed Framework for Personal Growth". SSRN Electronic Journal, 0-15.

Loon, M., Otaye-Ebede, L., \& Stewart, J. (2019) "The Paradox of Employee Psychological Well-Being Practices: An Integrative Literature Review and New Directions for Research". International Journal of Human Resource Management, 30(1), 156-187.

Ludermir, A. B., \& Lewis, G. (2003) "Informal Work and Common Mental Disorders". Social Psychiatry and Psychiatric Epidemiology, 38(9), 485-489.

Martela, F. (2014) "Sharing Well-Being in a Work Community? Exploring Well-BeingGenerating Relational Systems". Research on Emotion in Organizations: Vol. 10. Emotions and the Organizational Fabric, 4-79.

Montpetit, M. A., \& Tiberio, S. S. (2016) "Probing Resilience: Daily Environmental Mastery, Self-Esteem, and Stress Appraisal". International Journal of Aging and Human Development, 83(4), 311-332.

Njoda Mathurin, T. (2017) "The Wage Effect of Informal Sector in Developing Countries". Journal of World Economic Research, 4(5), 53.

Oun, M. A., \& Bach, C. (2014) "Qualitative Research Method Summary". Journal of Multidisciplinary Engineering Science and Technology (JMEST), 1(5), 3159-3199.

Perron, B. E. (2006) "A Critical Examination of the Environmental Mastery Scale". Social Indicators Research, 79(1), 171-188.

Reis, H. T., \& Collins, W. A. (2004) "Relationships, Human Behavior, and Psychological Science". Current Directions in Psychological Science, 13(6), 233-237.

Ryff, C. D. (1989) "Happiness is Everything, or Is It?". Journal of Personality and Social Psychology, 57(6), 1069-1081.

Ryff, C. D., \& Keyes, C. L. M. (1995) "The Structure of Psychological Well-Being Revisited". Journal of Personality and Social Psychology, 69(4), 719-727.

Ryff, C. D., \& Singer, B. (1996) "Psychological Well-Being: Meaning, Measurement, and Implications for Psychotherapy Research". Psychotherapy and Psychosomatics, 65(1), $14-23$.

Ryff, C. D., \& Singer, B. H. (2006) "Know Thyself and Become What You Are: A Eudaimonic Approach to Psychological Well-Being". Journal of Happiness Studies, 13-39.

Simonen, K. (2014) "Life Cycle Assessment: Past, Present and Future". Life Cycle Assessment, 45(1), 1-159.

Sychareun, V. (2016) "Informal Workers and Access to Healthcare: A Qualitative Study of 
Facilitators and Barriers to Accessing Healthcare for Beer Promoters in the Lao People's Democratic Republic". International Journal for Equity in Health, 1-10.

Tambunan, T. T. H. (2010) "The Indonesian Experience with Two Big Economic Crises". Modern Economy, 01(03), 156-167.

Tuffour, I. (2017) "A Critical Overview of Interpretative Phenomenological Analysis: A Contemporary Qualitative Research Approach". Journal of Healthcare Communications, 02(04), 1-5.

Williams, C. C. (2014) "Out of the Shadows: A Classification of Economies by the Size and Character of Their Informal Sector". Work, Employment and Society, 28(5), 735-753.

Winefield, A. H. (2010) "Unemployment, Underemployment, Occupational Stress and Psychological Well-Being". Australian Journal of Management, 27(1), 137-148.

Zamzami, M. K (2019) "Dilarang Parkir Mobil di Jalan Pemukiman". Harian Suara Merdeka. Semarang. 